\title{
Figures and Institutions of the neurological sciences in Paris from 1800 to 1950. Introduction and \\ Part I: Neuroanatomy
}

\section{Les figures et institutions des sciences neurologiques à Paris de 1800 à 1950. Introduction et Partie I: Neuroanatomie}

\author{
François Clarac ${ }^{1}$, Jean-Gaël Barbara ${ }^{2}$ \\ Emmanuel Broussolle ${ }^{3}$, Jacques Poirier ${ }^{4}$
}

1 : CNRS, UMR 6196, Laboratoire Plasticité et Physiopathologie de la motricité, Université AixMarseille II, Marseille, France

2 : CNRS, UMRS 7102, Laboratoire de neurobiologie des processus adaptatifs ; Université Pierre et Marie Curie ; CNRS UMR 7219, Laboratoire SPHERE, Université Denis Diderot ; Paris, France

3: Université Claude Bernard Lyon I ; Hospices Civils de Lyon, Hôpital Neurologique Pierre Wertheimer, Service de Neurologie C ; CNRS UMR 5229, Centre de Neurosciences Cognitives ; Lyon, France

4 : Professeur Honoraire, Hôpital Pitié-Salpêtrière ; Paris, France

Correspondance : Pr. Emmanuel Broussolle, Service de Neurologie C, Hôpital Neurologique Pierre Wertheimer, 69677, Bron Cedex, France

Key words: History, Paris, Neurosciences, Anatomy, Physiology, Neurology, Psychiatry, Psychology

Mots-clés : histoire, Paris, neurosciences, anatomie, physiologie, neurology, psychiatrie, psychologie

\section{Abstract}

We present a short historical review on the major institutions and figures that contributed to make Paris a renowned centre of physiology and neurology during the XIX ${ }^{\text {th }}$ and the first half of the $\mathrm{XX}^{\text {th }}$ centuries. We purposely chose to focus on the period $1800-1950$, as 1800 corresponds to the actual beginning of neuroscience, and 1950 marks their exponential rise. Our presentation is divided into four chapters, matching the main disciplines which have progressed and contributed the most to the knowledge we have of the brain sciences: anatomy, physiology, neurology, and psychiatrypsychology. The present article is the first of four parts of this review which includes an introduction followed by the chapter on neuroanatomy which includes biographical sketches of Félix Vicq d'Azyr, François Xavier Bichat, Franz Joseph Gall, Jean Cruveilhier, Jules Bernard Luys, Paul Broca, Louis Ranvier, André Victor Cornil, Albert Gombault, Jean Nageotte and René Couteaux. 


\section{Résumé}

Nous présentons une revue générale historique brève sur les principales institutions et personnalités ayant contribué à faire de Paris un centre renommé de physiologie et de neurologie au cours du $\mathrm{XIX}^{\mathrm{e}}$ siècle et de la première partie du $\mathrm{XX}^{\mathrm{e}}$ siècle. La raison du choix de cette période allant de 1800 à 1950 s'explique par le fait que 1800 marque les débuts des neurosciences, et 1950 leur développement exponentiel. Notre présentation est divisée en quatre chapitres, correspondant aux principales disciplines ayant progressé et contribué le plus aux connaissances que nous avons sur les sciences du cerveau : anatomie, physiologie, neurologie, et psychiatrie-psychologie. Le présent article est la première des quatre parties de cette revue générale, qui inclut une introduction générale puis le chapitre sur la neuroanatomie, avec les biographies résumées de Félix Vicq d'Azyr, François Xavier Bichat, Franz Joseph Gall, Jean Cruveilhier, Jules Bernard Luys, Paul Broca, Louis Ranvier, André Victor Cornil, Albert Gombault, Jean Nageotte et René Couteaux. 


\section{Introduction}

During the last decades, neuroscience research has experienced a tremendous growth in many fields of interest, notably in the anatomical, physiological, neurological or psychiatric domains. However, most of today's young scientists and physicians do not have sufficient historical background of these fascinating disciplines. Numerous authors from many parts of the world contributed to the development of the neurosciences and particularly neurology (Clarac and Boller, 2010; Clarac and Ternaux, 2008; Finger, 1994, 2000; Haymaker and Schiller, 1953; Rancurel et al., 2004). As early as the XIX ${ }^{\text {th }}$ century, special credit should be given to German speaking universities from Central Europe, institutions in Great Britain and North America, French and Italian neurological schools, and also medical universities from Belgium, the Netherlands, Scandinavia, Southern Europe, Russia and subsequently from South America, Asia and Africa during the $\mathrm{XX}^{\text {th }}$ century.

We took the opportunity of the $\mathrm{XV}^{\text {th }}$ Annual Meeting of the International Society for the History of the Neurosciences, held in Paris in June 2010, to prepare a historical work in order to make a short presentation of the major institutions and figures who contributed to make Paris a renowned centre of physiology and neurology between the $\mathrm{XIX}^{\text {th }}$ and the first half of the $\mathrm{XX}^{\text {th }}$ century. We purposely chose to focus on the period 1800-1950, as 1800 corresponds to the actual beginning of neurosciences, and 1950 marks its rise.

The beginning of the $\mathrm{XIX}^{\text {th }}$ century in France was characterized by a remarkable improvement of the medical and physiological knowledge. This was due to the influence of several combined factors. First, the XVIII ${ }^{\text {th }}$ century Enlightenment and the Mouvement Encyclopédique (Encyclopedic Movement), with an emerging scientific approach of philosophy (positivism and materialism). Second, the French Revolution, with marked restructuring of the French hospital system (establishment of internship/residentship and externship in 1802) and of the academic organization (re-foundation of the three Écoles de Santé - Medical faculties - in 1794). Third, the simultaneous presence of exceptional figures as François de Fourcroy (1715-1809), Pierre-Jean Georges Cabanis (1757-1808) and Philippe Pinel (1745-1826) to name but a few among the pioneers.

In 1830, there were numerous hospitals in Paris, in which 5000 medical students were working and where more than 20000 patients were treated. Three medical faculties were developed at that time, in Paris, Montpellier and Strasbourg, respectively. The other major cities such as Lyon, Marseille, Bordeaux, Lille or Toulouse only had medical schools which did not become faculties of their own right before the end of $\mathrm{XIX}^{\text {th }}$ century and the beginning of the $\mathrm{XX}^{\text {th }}$ century.

To put it shortly, the XIX ${ }^{\text {th }}$ century in France - in what regards the scientific domain - was deeply marked by two major conflicting ideologies. As illustrated by Cabanis in his Rapport du physique et du moral (Essay on Body and Mind) published in 1802 in which he considered that "le cerveau sécrète la pensée comme le foie sécrète la bile" (the brain secretes the thought, just like the liver secretes bile) (Cabanis et al., 1802), the materialists claimed that the human psyche was to be understood uniquely with the help of physiology. They adopted the positivism of Auguste Comte (1798-1857) and his denial of the spiritualist psychology. Just like Émile Zola's (1840-1902) Docteur Pascal, they were convinced that the advances of Science would bring happiness to the world (Zola, 1893). On the opposite, conservatives - who had the support of the royalist side and religious authorities - followed the ideas of Descartes and defended the body-mind dualism.

We have limited this presentation to Paris and its surroundings because the French capital, unlike in other cities, have long been the focal point of the country. After the reigns of Louis XIV and of Napoléon, everything was centralized in Paris, thus giving only a minor role to other cities. This explains why many of the figures we are going to evoke in this article "went up" to Paris, in search of a successful career. Our presentation will be divided into four chapters, matching the four disciplines which have progressed and contributed the most to the knowledge we have of the brain sciences: anatomy, physiology, neurology, and psychiatry-psychology. 


\section{Part I. Neuroanatomy}

In the $\mathrm{XIX}^{\text {th }}$ century, the anatomical studies concerning the nervous system were mainly dedicated to first the neuron, second the cerebral cortex.

The nerve cell - which was termed the neuron in the 1890s by Heinrich Wilhelm Gottfried von Waldeyer-Hartz (1836-1921) after the work of Santiago Ramón y Cajal (1852-1934), Wilhelm His (1831-1904) and August Henri Forel (1848-1931) - appeared to have the same essential characteristics as all the other cells of the living beings despite its particularities, thus confirming the cellular theory that had already been enounced in 1839 by two other German biologists Theodor Schwann (1810-1882) and Matthias Schleiden (1804-1881).

Earlier, in the first half of the XIX ${ }^{\text {th }}$ century, two French anatomists François Leuret (17971851), psychiatrist and student of Jean-Etienne Esquirol (1772-1840), and zoologist Pierre Gratiolet (1815-1865) took major steps forwards in our knowledge of the cortex. The fundamental data from their work Anatomie comparée du système nerveux (Comparative Anatomy of the Nervous System) allowed an accurate localization of the different areas of the brain. Leuret defined lobes and gyri as primary points of comparative anatomy on which are based the psychic functions (Leuret, 1857a, 1857b). Gratiolet complemented the results of his colleague by describing five lobes (frontal, parietal, temporal, occipital and insular) in each cerebral hemisphere, and the optic radiations that allow the connexion between the thalamus and the visual cortex (Gratiolet, 1861). In 1840, the French psychiatrist Jules Gabriel François Baillarger (1809-1890) brought to light six cortical layers - in turn transparent or opaque - while working on thin sections of the cortex with a microscope (Baillarger, 1840). This stratification has been adopted and enhanced outside France by Robert Remak (1815-1865) (Remak, 1838, 1841, 1847) and Albert von Kölliker (1817-1905) in 1841 and 1850, respectively (Kölliker, 1850; Eulenburg et al., 1900). These works on the brain led to intense arguments between the localisationists, who claimed that each area of the brain had its own function, and the unitarians who thought that the whole brain achieved all the functions. During the $\mathrm{XIX}^{\text {th }}$ century, French histologists were going to Germany to learn the different new techniques, in particular in the laboratory of Rudolf Virchow (1821-1902). However, with Louis Ranvier (18351922) and its great anatomical influence, anatomy and histology became very potent disciplines, a real school was started in Paris, and continued with René Couteaux (1909-1999), Jacques Taxi and André Calas. Following this introductory paragraph on the scientific context of the time, we will now present - without being exhaustive - a biographical sketch of several scientists who worked in Paris and greatly contributed to our knowledge of brain anatomy.

\section{Félix Vicq d’Azyr (1746-1794)}

Born in Normandy, Vicq d'Azyr (Figure 1) (Farrell and McHenry, 1987; Goldblatt, 1986; Hannaway, 1994; Mandressi, 2008; Mercado et al., 2004; Parent, 2007; Sournia, 1994; Stafford et al., 1992; Van Gijn, 2009) studied medicine in Paris and was the protégé of Antoine Petit (17221794), a professor of anatomy at the former Jardin du Roi (King's garden), current Jardin des Plantes (Paris Botanical garden). Vicq d'Azyr, a person of poor health, returned to Normandy in 1773, where he studied fish. After the publication of his work, and with the support of two of his masters, Marie Jean Antoine Nicolas de Caritat, Marquis de Condorcet (1743-1794) and Louis Daubenton (1715-1799), he became a member of the Académie des Sciences (French Academy of Sciences) in 1774. In the same year, he was given the responsibility of analyzing a severe "cattle epizootic" by the Contrôleur des Finances (finance Minister) Anne-Robert Turgot (1727-1781) (Meynell, 1998). He travelled across the French provinces and made suggestions to avoid the propagation of this epidemic. His report led Jacques Necker (1732-1804) - the successor of Turgot - to create the Société Royale de Médecine (Royal Society of Medicine), in charge of analyzing 
diseases and their treatments throughout the kingdom, society of which he became the perpetual secretary and Joseph Marie François Lassone (1717-1788) the president. Vicq d'Azyr contributed fundamentally to the study of anatomy and especially human brain anatomy (Vicq d'Azyr, s.d., 1779, 1780, 1784, 1786a, 1805). In 1786, Vicq d'Azyr published his Traité d'anatomie comparée et de physiologie (Treatise on Comparative Anatomy and Physiology), a remarkable anatomy and physiology treatise illustrated by sections of the human brain of a quality and exactitude never attained before (Vicq d'Azyr, 1786b, 1786c). He presented the deep brain structures and was the first one to describe the locus coeruleus, the locus niger and the mammillothalamic tract, also known as bundle of Vicq d'Azyr. We owe him the concept "homology" in biology. During the French Revolution, he presented a decisive plan to reform the teaching of medicine in France, and encouraged François de Fourcroy to have the three Écoles de Santé (Medical Faculties) re-created, in Paris, Montpellier and Strasbourg voted by the convention in 1794 (Peumery, 2001) .

\section{François Xavier Bichat (1771-1802)}

Bichat (Figure 2) was born in Thoirette in the Jura French département (County) and trained in medicine in Lyon under the guidance of the young surgeon Marc-Antoine Petit (1766-1811). He joined the Army of the Alps as a surgeon during the French Revolution. In 1794 he collaborated with Pierre Desault (1738-1795) at the Hôtel-Dieu hospital in Paris, until the sudden death of Desault which left Bichat alone, when aged 24. He compiled and published in a single piece of work, the lessons taught by his two masters and was appointed chief surgeon at the Hôtel-Dieu hospital, when he was only 29. In 1796, he founded the Société Médicale d'Émulation (Medical Society of Emulation), one of the most prestigious scientific associations of that time. Bichat investigated the pathology of diseases (Albury, 1977; Anonymous, 1968b, 1971; Baudet, 1969; Binet, 1959; Breathnach, 1981a; Elaut, 1969; Fye, 1996; Godlewski, 1968; Haas, 1994; Haigh, 1975, 1984; Heywood, 1979; McIntyre, 2004; Prichard, 1979; Shoja, 2008). Gaspard Laurent Bayle (1774-1816), René Théophile Laënnec (1781-1826) and Guillaume Dupuytren (1777-1835), three students of Bichat, members of this Society, founded the famous anatomo-clinical School of Paris (Anonymous, 1968a). At the same time Bichat began to give private lectures on anatomy and operative surgery. He published several major treatises such as Le Traité des membranes (A Treatise on the Membranes), in July 1799 (Bichat, 1799). He soon after attempted to explain the passage from life to death with anatomical, physiological and pathological analyses, by observing the way the different organs of the human body interact, in Recherches physiologiques sur la vie et la mort (Physiological Researches on Life and Death) in which he opposed the notion of vie de relation (animal life) to the one of vie végétative (organic life) (Bichat, 1800). In his Traité d'anatomie générale appliquée à la physiologie et à la médecine (General Anatomy Applied to Physiology and Medicine) published in 1801, he defined the notion of tissue by dividing organs into 21 elementary tissues, by dissection and without using a microscope (Bichat, 1801).

\section{Franz Joseph Gall (1758-1828)}

German physician and anatomist, Gall (Figure 3) first studied medicine at the university of Strasbourg and then at the university of Vienna. He became a professor and a brilliant neuroanatomist (Critchley, 1965; Ellis, 2008; Kaitaro, 2001; Lechtenberg, 1992; Lesky, 1970; Livianos-Aldana et al., 2007; Macmillan, 1992; Pardue, 1998; Rawlings and Rossitch, 1994; Simpson, 2005; Van Wyhe, 2002; Young, 1968; Zola-Morgan, 1995). Gall invented a new method of dissecting the brain, which helped him to make great progresses in the understanding of brain function (Gall, 1808, 1822a, 1822b, 1823a, 1823b, 1825, 1832). He supported the idea that psychic functions have a concrete localization within the brain. He was expelled from Austria and he 
subsequently came to France where his theories met a great success, despite being invalidated by the Académie des Sciences. Gall coined the term cranioscopy, name he gave to his method of attempting to associate the different gyri of the surface of the cortex with psychic properties, but his main disciple Johann Christoph Spurzheim (1766-1833) renamed it phrenology in 1810 (Spurzheim and Gall, 1809), term still used today. He distinguished 27 mental faculties at the surface of the brain, which he stratified into 3 groups:

- The first one is shared by all the vertebrates and is located in the posterior and lower parts of encephalon and includes: "l'instinct de propagation, l'amour de la progéniture, l'attachement et l'amitié, le goût pour les rixes et les combats, le penchant pour le meurtre, le penchant pour la ruse, le sentiment de propriété.... ('the reproduction instinct, the love of one's offspring, attachment and friendship, the taste for fighting and brawl, the tendency to murder and cunning, and the feeling of property").

- The second, found in higher vertebrates, is located in the inferior part of the anterior lobes. There are to be found "la mémoire des choses et des faits, le sens des localités et des rapports dans l'espace, la mémoire des personnes, le sens des mots et des noms, la mémoire verbale, le sens du langage et de la parole" ("the memory of facts and things, the sense of places and space proportions, the memory of persons, the sense of words and names, the verbal memory and the sense of language and speech").

- The third group is proper to humans and is located in the upper part of the anterior lobes (prefrontal area). It includes "la sagesse comparative, l'esprit métaphysique et la profondeur de l'esprit..." ("the comparative sagacity, the sense of metaphysics and the depth of the mind").

Despite the examination of hundreds of brains and skulls, phrenology does not have a scientific backing, as the correlations it pretends to establish between anatomy and behavioural observation remain very subjective. Harshest criticism of phrenology originated from Marie Jean Pierre Flourens (see Neurophysiology chapter).

\section{Jean Cruveilhier (1791-1874)}

Jean Cruveilhier (Figure 4), was born in Limoges in the center of France (Androutsos and Vladimiros, 2006; Anonymous, 1976; Bakay, 1989; Flamm, 1973; Pearce, 2003; Tainmont, 2009; Waring, 1968). He made a career in Paris with the support of the famous surgeon Guillaume Dupuytren (1777-1835) (Orcel and Vetter, 1976). In 1826 he reinstated the Société anatomique (Anatomical Society) that had been dissolved in 1808, and was appointed médecin des hôpitaux de Paris (senior physician of Paris hospitals) and then became head of a department of medicine at La Salpêtrière hospital the same year. In 1825 he was appointed professor of anatomy at the Paris Faculty of Medicine and became in 1835 the first occupant of the recently founded chair of pathology. His three major works are l'Anatomie descriptive (Descriptive Anatomy) (Cruveilhier, 1834a, 1834b), the outstanding Atlas d'Anatomie pathologique du corps humain (Atlas of Human Pathology) (Cruveilhier, 1828, 1829) and the Traité d'anatomie pathologique (Treatise on Pathology) in five volumes (Cruveilhier, 1849). He was the first to describe cholesteatoma - also referred to as tumeur perlée de Cruveilhier (pearly tumor of Cruveilhier) - and was also one of the first to give an anatomical description of the multiple sclerosis pathology, later individualised on the clinical level by Vulpian and Charcot.

\section{Jules Bernard Luys (1828-1897)}

Médecin des hôpitaux de Paris, head of a department of medicine at La Salpêtrière hospital and then at the Charité Hospital in Paris, Luys ( $\underline{\text { Figure 5 }}$ ) studied two very distinct areas. He made crucial discoveries in the field of neuroanatomy, giving the first description of the centro-median nucleus of the thalamus and of the subthalamic nucleus (Figure 6) (Luys, 1865). This nucleus was 
improperly coined by Luys bandelette acessoire des olives supérieures (accessory band of the superior olives) and later named Luys 'schen corpus or corpus Luysii (Luys body) by August Henri Forel (1848-1931) in 1877 (Beck, 2008; Parent, 2002; Pearce 2001). He also published the very first photographic atlas of the encephalon and an outstanding atlas representing drawings of sections of the brain (Luys, 1873). At the end of his career Luys probably followed the trend of that time and decided to study the completely different field of mental pathology, and focused particularly on hysteria and hypnosis dedicating many works to these two conditions (Parent et al., 2002). He was a member of l'Académie de médecine (Academy of medicine), and one of the founders of the journal L'Encéphale.

\section{Paul Broca (1824-1880)}

Broca (Figure 7) was born in a Protestant family, in Sainte Foy-la-Grande, a small town in the Gironde département, near Bordeaux, where several illustrious men (including Gratiolet) were born (Anonymous, 1980; Bendiner, 1986; Breathnach, 1981b; Cambier, 1980; Castaigne, 1980; Finger, 2004; Frédy, 1996; Huard, 1961; Jay, 2002; Monod-Broca, 1980, 2001, 2005, 2006; Rössner, 2007; Valette, 1980). He was successively interne des hôpitaux de Paris (intern/resident of Paris hospitals), surgeon of the hospitals, professor at the faculty of medicine of Paris and member of the Académie de medicine. Broca is mostly renowned as a scientist in the fields of neurology (Broca, 1853, 1866; Houdart, 1980; D’Aubigné, 1980; Gusmao, 2002), anatomy (Bonamy et al., 1866; Delmas, 1980; Huard, 1980; Denoix, 1980) and anthropology (Androutsos et Diamantis, 2007; Broca, 1862, 1871, 1873a, 1873b, 1873c, 1874, 1875, 1876, 1877a, 1879b; Clower, 2001; Pineau, 1980; Schiller, 1992). He made major steps in the study of cerebral localizations (Broca, 1877, 1879a; Cowie, 2000; Stone, 1991). His name is associated to a speech disorder, Broca's aphasia, which he described thanks to the anatomoclinical observation of the foot lesions of the left ascending frontal convolution in his patient Leborgne (Alajouanine, 1980; Broca and Nicolas, 2004). This Bicêtre'patient called "Tan" within the hospital because this was all he could say, apart from monosyllabic words and a curse. In a paper published in 1861 in Bulletins de la Société Anatomique de Paris, Broca presented a detailed account of his post-mortem examination of Tan's brain (Broca, 1861). In 1865, Broca proposed that the area for language was lateralized (Broca, 1865; Harris, 1991, 1993; Huard et al., 1982; Lee, 1981; Schiller, 1983). The "priority" of Broca's observation, its accuracy and the name that should be given to the syndrome were all disputed in public discussions and papers (Brown and Shobor, 1992; Roch Lecours, 1999). In 1863 Gustave Dax (1815-1893) came forth with a report prepared by his deceased father, Marc Dax (1770-1837), one supposedly presented to the Montpellier Medical Society in 1836. There is no question that Dax's paper on the left hemisphere dominance for speech had been written in 1836, but there remains the nagging issue of whether it had been a public document (Buckingham, 2006; Cubelli, 1994).

At the end of his life, in 1878, Broca described in great detail a region that forms the inner border of the brain. He analyzed it in different mammals' brains and called it the limbic region (Broca's great limbic lobe). Broca did not found its real function, and considered it associated with the olfactory system; we know today that it is linked with emotions (Broca, 1878).

Broca was the father of anthropology, and founded the Société d'anthropologie de Paris (Paris anthropological Society), the Revue d'Anthropologie (Topinard and Broca, 1876) and l'Ecole d'Anthropologie (School of Anthropology) in 1859, 1872 and 1876, respectively. Broca was a great humanist, a freethinker (he took part in the foundation of the Société des Libres Penseurs (Society of Freethinkers). He was a republican hostile to the Empire, and became a senator. The surgeon Ulysse Trélat (1728-1890) ended his eulogy with the following words: "Great and powerful intelligence, bright and serene soul, noble heart, what a rare and worthy trinity, magnificent union of everything that makes the true grandeur of the human being $[\ldots]$ " 


\section{Louis Ranvier (1835-1922)}

Born in Lyon, where he started his medical studies, Ranvier (igure 8) was admitted as an interne des hôpitaux de Paris in 1860 . He became a professor and was given a chair of general anatomy in 1875 at the Collège de France (the most prestigious scientific institution in France), where his teaching attracted considerable attention. Ranvier followed the experimental method taught by his master Claude Bernard (1813-1878), and always double-checked his morphological observations with the help of physiology (Barbara, 2006). His Manuel d'histologie pathologique (A Manual of Pathological Histology) in collaboration with Victor Cornil (1837-1908) is still considered as a masterpiece (Cornil and Ranvier, 1869). His numerous findings were related to bone and connective tissues, muscle histology (Ranvier and Renaut, 1880) and - above all - to nervous fibre histology (degeneration, regeneration and nerve endings) (Barbara, 2007; Ranvier, 1889; Ranvier and Weber, 1878). He discovered the annular constrictions of the nervous fibers (narrowing or nodes) named after him, as well as the T-structure of the axons of spinal ganglia sensory neurons. In 1897 Ranvier founded Archives d'anatomie microscopique with ÉdouardGérard Balbiani (1823-1899), the very first journal of microscopic studies. He was a member of the Académie des Sciences and of the Académie de Médecine. His main colleagues were Charles Malassez (1842-1909), Louis-Félix Henneguy (1850-1928), Édouard-Gérard Balbiani and JustinMarie Jolly (1870-1953) who held a chair of histophysiology at the Collège de France in 1925.

\section{André Victor Cornil (1837-1908)}

Cornil (Figure 9) had simultaneously a successful career in both medicine and politics (Anonymous, 1970). He was the oldest of Charcot's residents, a relentless worker, and was at the same time Médecin des Hôpitaux de Paris and professor of pathology. In 1882 he replaced Charcot who had taken over the chair dedicated to the study of the nervous system. Cornil was a clinician but also - and mainly- a pathologist. He was passionate about post mortem examinations and histopathology (Cornil, 1863, 1864, 1865, 1879, 1885). He wrote many papers and his Manuel d'histologie pathologique (A Manual of Pathological Histology) which he wrote in collaboration with Louis Ranvier, is a remarkably clear condensation of all his observations (Cornil and Ranvier, 1869). His collaboration with Ranvier began with the small private histological laboratory they founded on Rue Christine, and went on at the Collège de France and at the chair of Pathological anatomy. On the political level, Victor Cornil was a Congressional representative of the Allier French département (County), senator-mayor of his small village Creuzier-le-neuf, regional councillor, prefect from the 6th to the 24th of September 1870, and vice-president then president of the Regional Council of Allier. He was an anti-monarchist and presided over the Republican League in the 6th arrondissement of Paris during the Commune.

\section{Albert Gombault (1844-1904)}

Gombault (Figure 10) was resident of Charcot in 1872 and defended his MD thesis on amyotrophic lateral sclerosis in 1877 (Gombault, 1877). He was appointed Médecin des Hôpitaux de Paris in 1882 and head of a department of medicine at the Hopital des Incurables d'Ivry (current Charles Foix - Jean Rostand hospital). He was a founding member of the Société de Neurologie de Paris in 1899, chef des travaux anatomiques (chief of anatomical works) at the faculty of medicine and curator of the Musée Dupuytren. His neurological, neuropathological and neurohistological works are still of importance today (Clarac and Lechevalier, 2006; Gombault and Philippe, 1895). With official authorization from the Faculty of Medicine, he founded an open course on histology in 1887. He studied saturnism in guinea pigs that had been fed during six months with food containing lead. If there were no clear behavioural disturbances, most nervous fibers showed marked defects of myelin. Using the teasing method, he dissociated the nervous trunks of the brachial plexus and of the sciatic nerve. The axons always stayed intact but the Schwann cell sheaths were severely affected. These lesions might heal to some extent if lead ingestion was discontinued. Subsequently 
he demonstrated similar lesions in humans with lead poisoning. His pictures were reproduced in Greenfields Neuropathology, up to the 1976 edition. Gombault wrote the fifth part of the Traité d'histologie pathologique (Treatise on Pathological Histology, by Cornil and Ranvier), in collaboration with his beloved student Claude Philippe (1865-1903). He published several papers, but his name is more particularly associated with the névrite peri-axile (periaxial neuritis) of Gombault and Philippe (Gombault, 1880a, 1880b).

\section{Jean Nageotte (1866-1948)}

As a resident in 1889, Nageotte (Figure 11) defended his thesis on tabes dorsalis while working at the laboratory of Fulgence Raymond (1844-1910), at Lariboisière hospital (Nageotte, 1893). He was named médecin aliéniste des hôpitaux de Paris (psychiatrist of Paris hospitals) at Bicêtre hospital, then at the Salpêtrière hospital, and was head of Joseph Félix Babinski's (18571932) department for pathological and histological exams, where he designed a new brain microtome for the laboratory. He did several important reports on the human brain (Nageotte, 1911, 1913). In collaboration with Babinski, he described the Babinski-Nageotte syndrome of vascular lesion of the medulla in 1902 and published works on cerebrospinal fluid cytology (Babinski and Nageotte, 1902). He succeeded to Louis Ranvier and took over the chair of comparative histology (which had originally been created for Ranvier), when the latter left in 1937. Despite his achievements, Nageotte was never elected to the Académie des Sciences. In 1911 he paid a tribute to his teachers in the summary of his works, and especially to Albert Gombault of whom he had been a resident, to Louis-Charles Malassez (1842-1909), who accepted him in his laboratory and to Babinski. Nageotte did considerable research on the microscopic anatomy of the connective tissue (Nageotte, 1922, 1936, 1939) and of the nervous system and published a very detailed book entitled La structure fine du Système Nerveux (Fine Structure of the Nervous System) in 1905 (Nageotte, 1905). He then dedicated his research to myelin and physicochemical properties and published a book in 1937 entitled Morphologie des gels lipoïdes, myéline, cristaux liquides, vacuoles (Morphology of Lipoid Gels, Myelin, Liquid crystals and Vacuoles) (Nageotte, 1937). He was the teacher of René Couteaux. Following an accident Nageotte was struck down by hemiplegia and became progressively deaf.

\section{René Couteaux (1909-1999)}

Couteaux (Figure 12) was docteur en Médecine (MD), professor of histology and cytology at the Paris Faculty of Sciences and a pioneer in the anatomical and ultrastructural knowledge of synapses (Couteaux, 1941). He began his studies on the neuromuscular junction in 1935. On the biochemical level, he co-established with David Nachmanson (1899-1983) the concentration of the acetyl-cholinesterase activity in the neural area of muscle fibers even after denervation. Thanks to Janus green B staining, Couteaux defined the postsynaptic membrane, the subneural organization and the motor end plate and published his results in his $\mathrm{PhD}$ thesis in 1947 (Couteaux, 1947). After hearing a speech from Sanford Palay (1918-2002) at Caracas congress in 1957, from 1960 onwards, Couteaux decided to study the presynaptic portion of the synapse (Couteaux and PécotDechavassine, 1970b). In 1970, he managed to obtain characteristic images of the exocytosis by opening synaptic vesicles (Figure 13) (Couteaux and Picot-Dechavassine, 1970a; Tsuji, 2006).

\section{Acknowledgements}

The authors would like to thank Chloé Loiraud, Yann Bregeras, Sandrine Jamen and Jessica Moreau from Bibliothèque Médicale, Hôpital Neurologique Pierre Wertheimer, Lyon, France for 
their tremendous help, Chantal Barbara, Marjorie Lorch (ISHN), the École des Neurosciences de Paris, the Club d'Histoire des Neurosciences from the Sociéte des Neurosciences and the BIU Santé (Bibliothèque Inter Universitaire de Santé de Paris) and the Académie Nationale de Médecine and Académie des Sciences for the reproduction of photographs. 


\section{References}

Alajouanine T, Signoret JL. Paul Broca et l'aphasie. Bull Acad Natl Méd 1980;164:545-551.

Albury WR. Experiment and explanation in the physiology of Bichat and Magendie. Stud Hist Biol 1977;1:47-131.

Androutsos G, Diamantis A. Paul Broca (1824-1880): founder of anthropology, pioneer of neurology and oncology. J Buon 2007;12:557-564.

Androutsos G, Vladimiros L. The eminent French pathologist Jean Cruveilhier (1791-1874) and his works on cancer. J Buon 2006;11:369-376.

Anonymous. Bichat, Laennec et leur temps. Sem Hôp 1968;44:3346-3352.

Anonymous. Marie François Xavier Bichat (1771-1802), tissue pathologist. JAMA 1968;203:291292.

Anonymous. André-Victor Cornil (1837-1908). JAMA 1970;212:1371-1372.

Anonymous. Marie François Xavier Bichat 1771-1802. Triangle 1971;10:39-40.

Anonymous. Eponym: Cruveilhier-Baumgarten syndrome. South Med J 1976;69:1316.

Anonymous. Commémoration du centenaire de la mort de Paul Broca. Chirurgie 1980;106:773793.

Babinski J, Nageotte J. Hemiasynergie latéro-pulsion et myosis bulbaires avec hémianesthésie et hémiplégie croisées. Paris: Masson; 1902

Baillarger JGF. Recherches sur la structure de la couche corticale des circonvolutions du cerveau. Paris : Masson; 1840.

Bakay L. Cruveilhier on meningiomas (1829-1842). Surg Neurol 1989;32:159-164.

Barbara JG. Louis Antoine Ranvier (1835-1922). J Neurol 2006;253:399-400.

Barbara JG. Louis Ranvier (1835-1922): the contribution of microscopy to physiology and the renewal of French general anatomy. J Hist Neurosci 2007;16:413-431.

Baudet JH. Xavier Bichat (1771-1802). Presse Méd 1969;77:774.

Beck F, Kriz W, Pauly JE. Marani E, Heida T, Lakke EAJF, al.. The subthalamic nucleus; Part I: development, cytology, topography and connections. In: Beck F, Kriz W, Pauly JE, editors. Advances in anatomy, embryology, and cell biology. Berlin: Springer; 2008.

Bendiner E. Paul Broca: adventurer in the recesses of the mind. Hosp Pract 1986;21:104-112, 117, 120-121. 
Bichat X. Traité des membranes en général et de diverses membranes en particulier. Paris: impr. Richard Caille et Ravier; 1799.

Bichat F. Recherches physiologiques sur la vie et la mort. Paris: Brosson, Gabon et Cie; 1800.

Bichat X. Anatomie générale, appliquée à la physiologie et à la médecine. Paris: impr. Brosson, Gabon et Cie; 1801.

Binet L. A la gloire d'un grand médecin: Xavier Bichat (1771-1801). Biol Méd 1959;48:443-452.

Bonamy CL, Broca P, Beau É. Atlas d'anatomie descriptive du corps humain. Paris: Masson; 1866.

Breathnach CS. Bichat. Ir Med J 1981;74:4.

Breathnach CS. Biographical sketches no. 4. Broca. Ir Med J 1981;74:109.

Broca P. Du traitement des anévrysmes par la compression indirecte. Paris: V. Martinet; 1853.

Broca P. Remarques sur le siège de la faculté du langage articulé, suivie d'une observation d'aphémie (perte de la parole). Bulletins de la Société anatomique de Paris 1861;36:330-57.

Broca P. La linguistique et l'anthropologie. Paris: Masson; 1862.

Broca P. Sur le siège de la faculté du langage articulé dans l'hémisphère gauche du cerveau. Paris: Masson; 1865.

Broca P. Traité des tumeurs. Paris: P. Asselin; 1866.

Broca P. Mémoires d'anthropologie. Paris: Reinwald; 1871.

Broca P. De l'influence de l'éducation sur le volume et la forme de la tête. Paris: typ. A Hennuyer; 1873.

Broca P. Sur l'endocrâne, nouveaux instruments destinés à étudier la cavité crânienne, sans ouvrir le crâne. Paris: impr. A. Hennuyer; 1873.

Broca P. Sur la mensuration de la capacité du crâne. Paris: Reinwald; 1873.

Broca P. Études sur les propriétés hygrométriques des crânes considérées dans leurs rapports avec la craniométrie. Paris: typ. de A. Hennuyer; 1874.

Broca P. Nomenclature craniologique. Notions complémentaires sur l'ostéologie du crâne. Détermination et dénomination nouvelles de certains points de repère. Paris: typ. A Hennuyer; 1875.

Broca P. Sur la topographie crânio-cérébrale ou sur les rapports anatomiques du crâne et du cerveau. Paris: Ernest Leroux; 1876.

Broca P. De la différence fonctionnelle des deux hémisphères cérébraux. Paris: G. Masson; 1877.

Broca P. Sur l'angle orbito-occipital. Paris: Leroux; 1877. 
Broca P. Nomenclature cérébrale dénomination des divisions et subdivisions des hémisphères et des anfractuosités de leur surface. Paris: Masson; 1878.

Broca P. Localisations cérébrales: recherches sur les centres olfactifs. Rev Anthrop 1879;2:385455.

Broca P. Tables anthropologiques pour les mesures craniologiques et céphalométriques. Moscou: impr. Arkhipov ch Lavzov; 1879.

Broca P, Nicolas S. Écrits sur l'aphasie, 1861-1869. Paris: L'Harmattan; 2004.

Brown JW, Chobor KL. Phrenological studies of aphasia before Broca: Broca's aphasia or Gall's aphasia? Brain Lang 1992;43:475-486.

Buckingham HW. The Marc Dax (1770-1837), Paul Broca (1824-1880) controversy over priority in science: left hemisphere specificity for seat of articulate language and for lesions that cause aphemia. Clin Linguist Phon 2006;20:613-619.

Cabanis P, Crapart J, Caille C, Ravier L, Crapelet C. Rapports du physique et du moral de l'homme. Paris: Impr. Caille et Ravier; 1802.

Cambier J. Paul Broca, 100 ans après sa mort: 1880-1980. Nouv Presse Méd 1980;9:1983.

Castaigne P. Paul Broca (1824-1880). Rev Neurol (Paris). 1980;136:559-562.

Clarac F, Boller F. History of Neurology in France. In: Aminoff MJ, Boller F, Swaab DF editors. Handbook of clinical neurology - History of Neurology. Vol 95. Amsterdam: Elsevier; 2010. p. 629-656.

Clarac F, Lechevalier B. Albert Gombault (1844-1904). Un pionnier des neurosciences. Rev Neurol (Paris) 2006;162:253-263.

Clarac, F, Ternaux, JP. Encyclopédie historique des Neurosciences. Du neurone à l'émergence de la pensée. Bruxelles: DeBoeck Université; 2008.

Clower WT, Finger S. Discovering trepanation: the contribution of Paul Broca. Neurosurgery 2001;49:1417-1425; discussion 1425-1426.

Cornil V. Note sur les lésions des nerfs et des muscles liées à la contracture tardive et permanente des membres dans les hémiplégies. Paris: Impr. de E. Thunot; 1863.

Cornil V. Sur la production des tumeurs épithéliales dans les nerfs. Paris: G. Baillière; 1864.

Cornil V. Contributions à l'histoire du développement histologique des tumeurs épithéliales. Paris: G. Baillière; 1865.

Cornil V. Instruction sur le mode de conservation des pièces anatomiques destinées à être examinées au microscope. Paris: impr. Goupy et Jourdan; 1879.

Cornil V, Babes V. Les bactéries et leur rôle dans l'anatomie et l'histologie pathologiques des maladies infectieuses: ouvrage contenant les méthodes spéciales de la bactériologie. Paris: F. Alcan; 1885. 
Cornil V, Ranvier LA. Manuel d'histologie pathologique. Paris: Baillière; 1869.

Couteaux R. Recherches sur l'histogénèse du muscle strié des mammifères et la formation des plaques motrices. Paris: P.U.F; 1941.

Couteaux R. Contribution à l'étude de la synapse myoneurale. Montréal: Presses Universitaires de Montréal; 1947.

Couteaux R, Pécot-Dechavassine M. L'ouverture des vésicules synaptiques au niveau des "zones actives". In: Septième congrès international de microscopie électronique, Vol.3. Grenoble; 1970. p. 709-710.

Couteaux R, Pécot-Dechavassine M. Vésicules synaptiques et poches au niveau des 'zones actives' de la jonction neuromusculaire. CR Séances Acad Sci Ser D 1970;271: 2346-2349.

Cowie SE. A place in history: Paul Broca and cerebral localization. J Invest Surg 2000;13:297-298.

Critchley M. Neurology's debt to F. J. Gall (1758-1828). Br Med J 1965;2:775-781.

Cruveilhier J. Anatomie pathologique Atlas. Paris: J.-B. Baillière;1828.

Cruveilhier J. Anatomie pathologique du corps humain ou descriptions, avec figures lithographiées et coloriées, des diverses altérations morbides dont le corps humain est susceptible. Paris: J.B. Baillière; 1829.

Cruveilhier J. Anatomie descriptive. Paris: Béchet jeune; 1834.

Cruveilhier J. Traité d'anatomie descriptive. Paris: Aggolin;1834.

Cruveilhier J. Traité d'anatomie pathologique générale. Paris: J.-B. Baillière; 1849.

Cubelli R, Montagna CG. A reappraisal of the controversy of Dax and Broca. J Hist Neurosci 1994;3:215-226.

D'Aubigné RM. Paul Broca et la chirurgie de l'appareil moteur. Chirurgie 1980;106:791-793.

Delmas A. Paul Broca et l'anatomie. Bull Acad Natl Méd. 1980;164:552-556.

Denoix P. Paul Broca: l'anatomie pathologique, le cancer, la statistique. Chirurgie 1980;106:787790.

Elaut L. The theory of membranes of F. X. Bichat and his predecessors. Sudhoffs Arch 1969;53:6876.

Ellis H. Francis Joseph Gall (1758-1828): false prophet of cerebral localization. Br J Hosp Med 2008;69:173.

Eulenburg A, Jolly F, Kölliker A. Die Krankheiten des Nervensystems. Stuttgart: F. Enke; 1900.

Farrell PS, McHenry LC. Fragments of neurologic history: Félix Vicq d'Azyr and neuroanatomy. Neurology 1987;37:1349-1350. 
Flamm ES. The neurology of Jean Cruveilhier. Med Hist 1973;17:343-355.

Finger S. Origins of Neuroscience: A history of explorations into brain function. New York: Oxford University Press; 1994.

Finger S. Minds Behind the Brain: A History of the Pioneers and their Discoveries. New York: Oxford University Press; 2000.

Finger S. Paul Broca (1824-1880). J Neurol 2004;251:769-770.

Frédy D. Paul Broca (1824-1880). Hist Sci Méd 1996;30:199-208.

Fye WB. Marie-François-Xavier Bichat. Clin Cardiol 1996;19:760-761.

Gall FJ. Introduction au cours de physiologie du cerveau. Paris: s.n; 1808.

Gall FJ. Sur les fonctions du cerveau et sur celles de chacune de ses parties: avec des observations sur la possibilité de reconnaître les instincts, les penchans, les talens, ou les dispositions morales et intellectuelles des hommes et des animaux, par la configuration de leur cerveau et de leur tête. Paris: Boucher, Bossange père, Béchet jeune, J.B. Baillière; 1822.

Gall FJ. Sur l'origine des qualités morales et des facultés intellectuelles de l'homme et sur les conditions de leur manifestation. Paris: L'Auteur; 1822.

Gall FJ. Influence du cerveau sur la forme du crâne: difficultés et moyens de déterminer les qualités et les facultés fondamentales et de découvrir le siège de leurs organes. Paris: Boucher; 1823.

Gall FJ. Organologie ou exposition des instincts, des penchans, des sentimens et des talens ou des qualités morales et des facultés intellectuelles et du siège de leurs organes. Paris: Boucher; 1823.

Gall FJ. Revue critique de quelques ouvrages anatomico-physiologiques et exposition d'une nouvelle philosophie des qualités morales et des qualités intellectuelles. Paris: Boucher; 1825 .

Gall FJ. Précis du système phrénologique du docteur Gall. Paris: Garnier; 1832.

Gall FJ, Spurzheim JG. Anatomie et physiologie du système nerveux en général et du cerveau en particulier. Atlas. Paris: F. Schoell; 1810.

Godlewski G. Immortel Bichat. Sem Hôp. 1968;44:3353-3362.

Goldblatt D. The key to the brain. Félix Vicq d'Azyr (1748-1794). Semin Neurol 1986;6:231-237.

Gombault A. Etude sur la sclérose latérale amyotrophique. Thèse de médecine: Paris; 1877.

Gombault A. Contribution à l'étude anatomique de la névrite parenchymateuse subaiguë ou chronique - Névrite segmentaire périaxile. Arch Neurol 1880;1:11-38.

Gombault A. Contribution à l'étude anatomique de la névrite parenchymateuse subaiguë ou chronique - Névrite segmentaire périaxile. Paris: V.-A. Delahaye et Lecrosnier; 1880. 
Gombault A, Philippe C. Contribution à l'étude des lésions systématisées dans les faisceaux blancs de la moelle épinière. Gaz Heb Med Chir 1895;32:286-287.

Gratiolet P. Observations sur le poids et la forme du cerveau, lues à la Société d'anthropologie, dans la séance du 18 avril 1861. Paris: Typ. Hennuyer; 1861.

Gusmao S. Broca et les débuts de la neurochirurgie moderne. Hist Sci Méd 2002;36:423-427.

Haas LF. Marie François Xavier Bichat (1771-1802). J Neurol Neurosurg Psychiatry 1994;57:263.

Haigh E. The roots of the vitalism of Xavier Bichat. Bull Hist Med 1975;49:72-86.

Haigh E. Xavier Bichat and the medical theory of the eighteenth century. Med Hist Supp 1984; 4:1146.

Hannaway C. Vicq d'Azyr, anatomy and a vision of medicine. Clio Med 1994;25:280-295.

Harris LJ. Cerebral control for speech in right-handers and left-handers: an analysis of the views of Paul Broca, his contemporaries, and his successors. Brain Lang 1991;40:1-50.

Harris LJ. Broca on cerebral control for speech in right-handers and left-handers: a note on translation and some further comments. Brain Lang 1993;45:108-120.

Haymaker W, Schiller F. The Founders of neurology, one hundred and thirty-three biographical sketches prepared for the fourth International neurological congress in Paris, September 510 1949. Springfield: Ill., C. C. Thomas; 1953.

Heywood C. D. H. Lawrence's "blood consciousness" and the work of Xavier Bichat and Marshall Hall. Etud Angl 1979;32:397-413.

Houdart R. Paul Broca: précurseur des disciplines neurologiques. Chirurgie 1980;106:783-786.

Huard P. Paul Broca (1824-1880). Concours Méd 1961;83:4917-4920, 5069-5074.

Huard P. Paul Broca, anatomiste. Chirurgie 1980;106:774-776.

Huard P, Aaron C, Askienazy S, et al. The brain of Paul Broca (1824-1880). Correlation of pathological and computed tomography findings. J Radiol 1982;63:175-180.

Jay V. Pierre Paul Broca. Arch Pathol Lab Med 2002;126:250-251.

Kaitaro T. Biological and epistemological models of localization in the nineteenth century: from Gall to Charcot. J Hist Neurosci 2001;10:262-276.

Kölliker A. Mikroskopische anatomie, oder, Gewebelehre des menschen. Leipzig: Wilhelm Engelmann; 1850.

Lechtenberg R. Franz Gall. Neurology 1992;42:2057-2058.

Lee DA. Paul Broca and the history of aphasia: Roland P. Mackay Award Essay, 1980. Neurology 1981;31:600-602. 
Lesky E. Structure and function in Gall. Bull Hist Med 1970;44:297-314.

Leuret F. Anatomie comparée du système nerveux considéré dans ses rapports avec l'intelligence. Tome premier, comprenant la description de l'encéphale et de la moelle rachidienne. Paris: J.B. Baillière et fils; 1857.

Leuret F. Anatomie comparée du système nerveux considéré dans ses rapports avec l'intelligence. Tome second, comprenant l'anatomie du cerveau de l'homme et des singes. Paris: J.B. Baillière et fils; 1857.

Livianos-Aldana L, Rojo-Moreno L, Sierra-Sanmiguel P. F.J. Gall and the phrenological movement. Am J Psychiatry 2007;164:414.

Luys J. Recherches sur le système nerveux cérébro-spinal: sa structure, ses fonctions et ses maladies. Paris: J.B. Baillière et fils; 1865.

Luys J. Iconographie photographique des centres nerveux. Paris: J.B Ballière; 1873.

Macmillan M. Inhibition and the control of behavior. From Gall to Freud via Phineas Gage and the frontal lobes. Brain Cogn 1992;19:72-104.

Mandressi R. The past, education and science. Félix Vicq d'Azyr and the history of medicine in the $18^{\text {th }}$ century. Med Secoli 2008;20:183-212.

McIntyre N. Xavier Bichat (1771-1802). J Med Biogr 2004;12:184.

Mercado R, Santos-Franco J, Ortiz-Velazquez I, Gómez-Llata S. Vascular anatomy of the foramen of Vicq d'Azyr: a microsurgical perspective. Minim Invasive Neurosurg 2004;4:102-106.

Meynell E. Vicq d'Azyr and a cattle plague. J R Soc Med 1998;91:105-106.

Monod-Broca P. Paul Broca (1824-1880). Le chirurgien, l'homme. Bull Acad Natl Méd 1980;164:536-544.

Monod-Broca P. Paul Broca: 1824-1880. Ann Chir 2001;126:801-807.

Monod-Broca P. Paul Broca, un géant du XIXe siècle, Paris: Vuibert; 2005.

Monod-Broca P. L'autre Paul Broca. Rev Prat 2006;56:923-925.

Nageotte J. Tabes et paralysie générale. Thèse de Médecine: Paris; 1893.

Nageotte J. La structure fine du système nerveux. Paris: Maloine; 1905.

Nageotte J. Notice sur les travaux scientifiques. Paris: s.n; 1911.

Nageotte J. La carte de l'écorce cérébrale. Paris: Félix Alcan; 1913.

Nageotte J. L'organisation de la matière dans ses rapports avec la vie: études d'anatomie générale et de morphologie expérimentale sur le tissu conjonctif et le nerf: avec 152 figures dans le texte et 4 planches contenant 16 figures, dont 14 microphotographies autochromes. Paris: Félix Alcan; 1922. 
Nageotte J. Structures à surfaces hydrophobes, structures vacuolaires. Paris: Hermann; 1936.

Nageotte J. Morphologie des gels lipoïdes. Myéline. Cristaux liquides. Vacuoles. Paris: Hermann; 1937.

Nageotte J. Sur l'emploi des greffes de tissu conjonctif mort dans la chirurgie réparatrice (Tendon et Nerf). Paris: Masson; 1939.

Orcel L, Vetter T. Dupuytren, Cruveilhier and the anatomical society. Arch Anat Cytol Pathol 1976;24:167-179.

Pardue ML. Joseph Gall- pioneering nuclear biology. Trends Cell Biol 1998;8:208-210.

Parent A. Jules Bernard Luys and the subthalamic nucleus. Mov Disord 2002;17:181-185.

Parent A. Felix Vicq d'Azyr: anatomy, medicine and revolution. Can J Neurol Sci 2007;34:30-37.

Parent A, Parent M, Leroux-Hugon V. Jules Bernard Luys: a singular figure of 19th century neurology. Can J Neurol Sci 2002;29:282-288.

Pearce JM. The subthalamic nucleus and Jules Bernard Luys (1828-97). J Neurol Neurosurg Psychiatry 2001;71:783.

Pearce JM. Cruveilhier and acoustic neuroma. J Neurol Neurosurg Psychiatry 2003;74:1015.

Peumery JJ. Vicq d'Azyr et la Révolution Française. Hist Sci Méd 2001;35:263-270.

Pineau H. Paul Broca et l'anthropologie. Bul Acad Natl Méd 1980;164:557-562.

Prichard R. Selected items from the history of pathology: Marie-François-Xavier Bichat (17711802). Am J Pathol 1979;96:256.

Rancurel G, Delattre JY, Evrard P et al. Les noms en neurologie. Le Raincy: Éditions Congrès relation; 2004.

Ranvier LA. Traité technique d'histologie. Paris: Librairie F. Savy; 1889.

Ranvier LA, Renaut JL. Leçons d'anatomie générale sur le système musculaire recueillies par M. J. Renaut. Paris: Bureaux du Progrès Médical; 1880.

Ranvier LA, Weber É. Leçons sur l'histologie du système nerveux. Paris: Savy; 1878.

Rawlings CE, Rossitch E. Franz Josef Gall and his contribution to neuroanatomy with emphasis on the brain stem. Surg Neurol 1994;42:272-275.

Remak R. Observationes anatomicae et microscopicae de systematis nervosi structura: Accedunt duae tabulae aëri incisae. Berolini: Sumtibus et formis Reimerianis; 1838.

Remak R. Bericht über die Leistungen im Gebiele der Physiologie im Jahre 1841. Berlin: [s.n]; 1841.

Remak R. Ueber ein selbständiges Darmnervensystem. Berlin: G. Reimer; 1847. 
Roch Lecours A. Aphasie : querelles. Rev Neurol (Paris) 1999;150: 833-847.

Rössner S. Paul Pierre Broca (1824-1880). Obes Rev 2007;8:277.

Schiller F. Paul Broca and the history of aphasia. Neurology 1983;33:667.

Schiller F. Paul Broca, Founder of French Anthropology, Explorer of the brain. New York: Oxford University Press; 1992.

Shoja MM, Tubbs RS, Loukas M, Shokouhi G, Ardalan MR. Marie-François Xavier Bichat (17711802) and his contributions to the foundations of pathological anatomy and modern medicine. Ann Anat 2008;190:413-420.

Simpson D. Phrenology and the neurosciences: contributions of F. J. Gall and J.G. Spurzheim. ANZ J Surg 2005;75:475-482.

Sournia JC. Félix Vicq d'Azyr, inventeur de l'Académie de Médecine (1748-1794). Bull Acad Natl Méd 1994;178:1237-1243; discussion 1243-1244.

Spurzheim JG, Gall FJ. Recherches sur le système nerveux en général et sur celui du cerveau en particulier, mémoire présenté à l'Institut de France, le 14 mars 1808, suivi d'observations sur le rapport qui a été fait à cette Compagnie par ses commissaires. Paris: F. Schoell; 1809.

Stafford BM, Klein E, Haskins K, Liebman E, Teslow T. Depth studies: illustrated anatomies from Vesalius to Vicq d'Azyr. Caduceus 1992;8:39-48.

Stone JL. Paul Broca and the first craniotomy based on cerebral localization. J Neurosurg 1991;75:154-159.

Tainmont J. A historical vignette (14). The anatomo-clinical method applied to ENT at the time of Jean Cruveilhier. B-ENT 2009;5:129-136.

Topinard P, Broca P. L'Anthropologie. Paris: C. Reinwald; 1876.

Tsuji S. René Couteaux (1909-1999) and the morphological identification of synapses. Biol Cell 2006;98:503-509.

Valette G. Allocution prononcée lors de la séance au centenaire de la mort de Paul Broca (18241880). Bull Acad Natl Méd 1980;164:535.

Van Gijn J. Félix Vicq d'Azyr (1748-1794). J Neurol 2009;256:1384-1385.

Van Wyhe J. The authority of human nature: the Schädellehre of Franz Joseph Gall. Br J Hist Sci 2002;35:17-42.

Vicq d'Azyr F. Discours sur l'anatomie comparée suivis du tableau des fonctions ou caractères propres aux corps vivants. Paris: s.n.; s.d.

Vicq d'Azyr F. Observations anatomiques. In: Mémoires de l'Académie Royale des Sciences. Paris: impr. Royale; 1779. p.700-703. 
Vicq d'Azyr F. Mémoire sur la description des nerfs de la seconde et troisième paire cervicale. In: Mémoires de l'Académie Royale des Sciences. Paris: impr. Royale; 1780. p. 21-40.

Vicq d'Azyr F. Second mémoire contenant des observations sur plusieurs régions du cerveau disséqué par sa base, et sur l'origine des nerfs. In: Mémoires de l'Académie Royale des Sciences. Paris: impr. Royale; 1784:543-566.

Vicq d'Azyr F. Suite des recherches sur la structure du cerveau. Quatrième mémoire. Sur la structure du cerveau des animaux comparé avec celui de l'homme. In: Mémoires de l'Académie Royale des Sciences. Paris: impr. Royale; 1786:468-504.

Vicq d'Azyr F. Traité d'anatomie et de physiologie avec des planches coloriées représentant au naturel les divers organes de l'Homme et des Animaux, Vol I. Paris: Impr. F. A. Didot l'ainé; 1786.

Vicq d'Azyr F. Traité d'anatomie et de physiologie avec des planches coloriées représentant au naturel les divers organes de l'Homme et des Animaux, Vol II (planches). Paris: Impr. F. A. Didot l'ainé; 1786.

Vicq d'Azyr F. Oeuvres complètes. Textes recueillis par Jacques Louis Moreau de la Sarthe. Paris: Duprat Duverger; 1805.

Waring JI. William Middleton Michel in Paris, 1842-1846. A vignette of Cruveilhier. J Hist Med Allied Sci 1968;23:349-355.

Young RM. The functions of the brain: Gall to Ferrier (1808-1886). Isis 1968;59:25-68.

Zola E. Le Docteur Pascal. Paris: G. Charpentier et E. Fasquelle; 1893.

Zola-Morgan S. Localization of brain function: the legacy of Franz Joseph Gall (1758-1828). Annu Rev Neurosci 1995;18:359-383. 


\section{Figures}

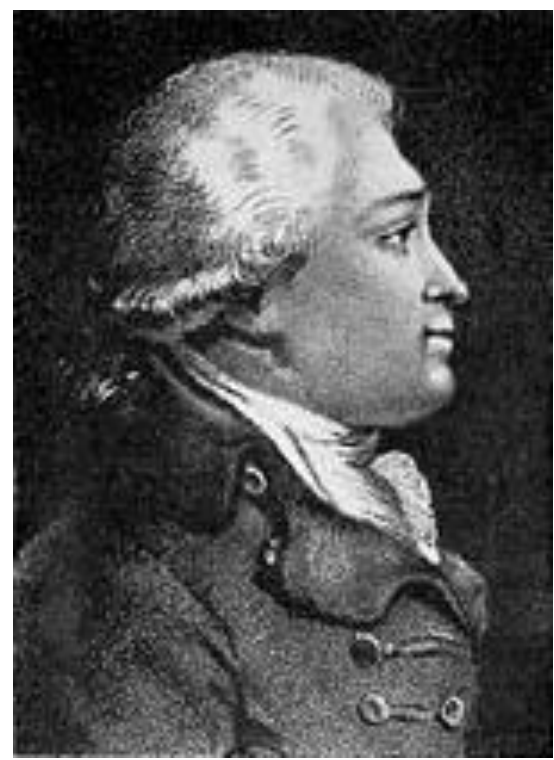

Figure 1. Picture of Vicq D'azyr. Portrait de Vicq D'Azyr (Académie Nationale de Médecine).

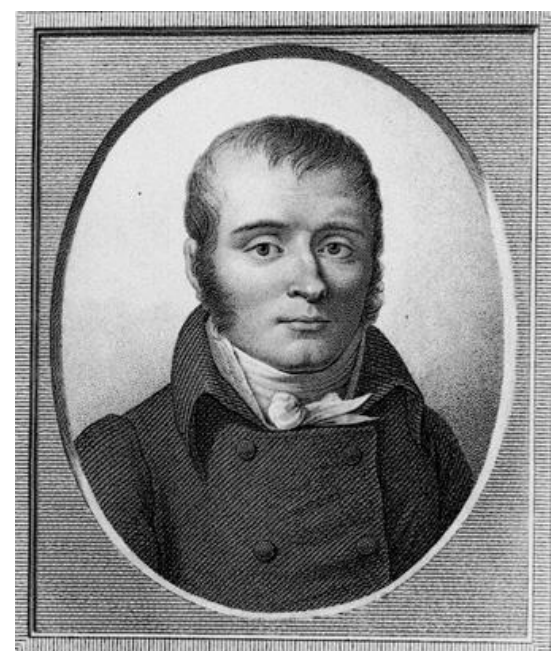

Figure 2. Picture of Bichat. Portrait de Bichat (CBIU Santé).

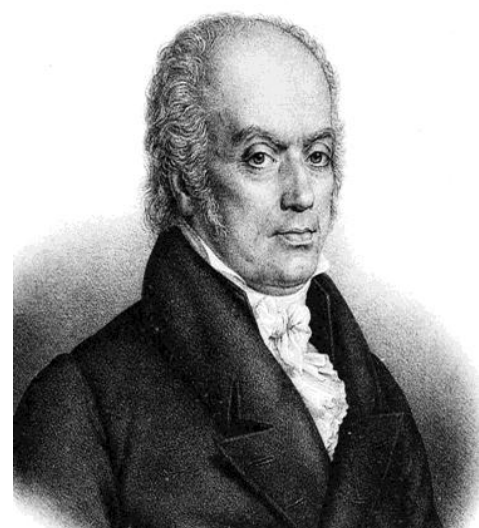

Figure 3. Picture of Gall. Portrait de Gall (CBIU Santé). 


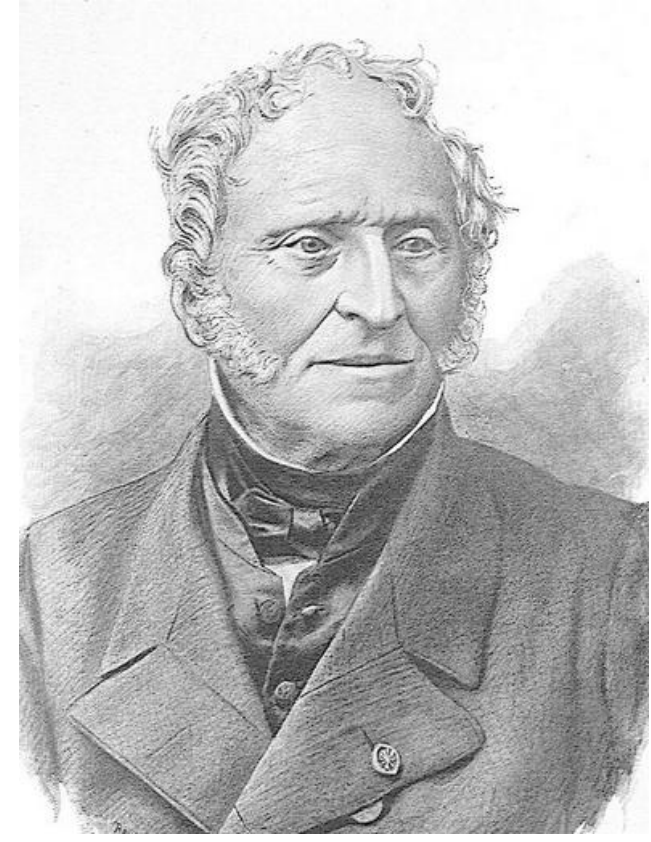

Figure 4. Picture of Cruveilhier. Portrait de Cruveilhier (Académie Nationale de Médecine).

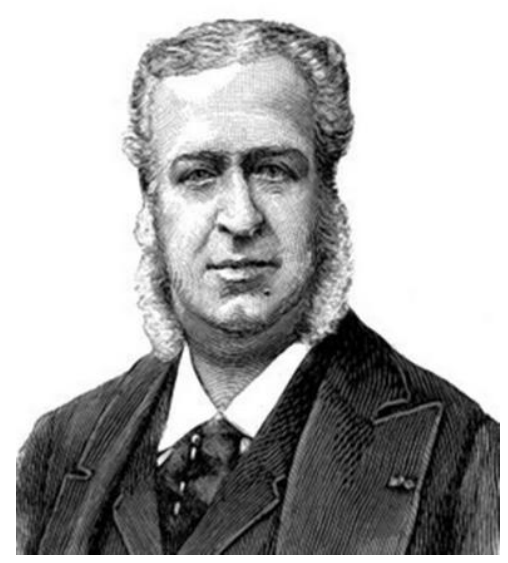

Figure 5. Picture of Luys. Portrait de Luys (Académie Nationale de Médecine). . 


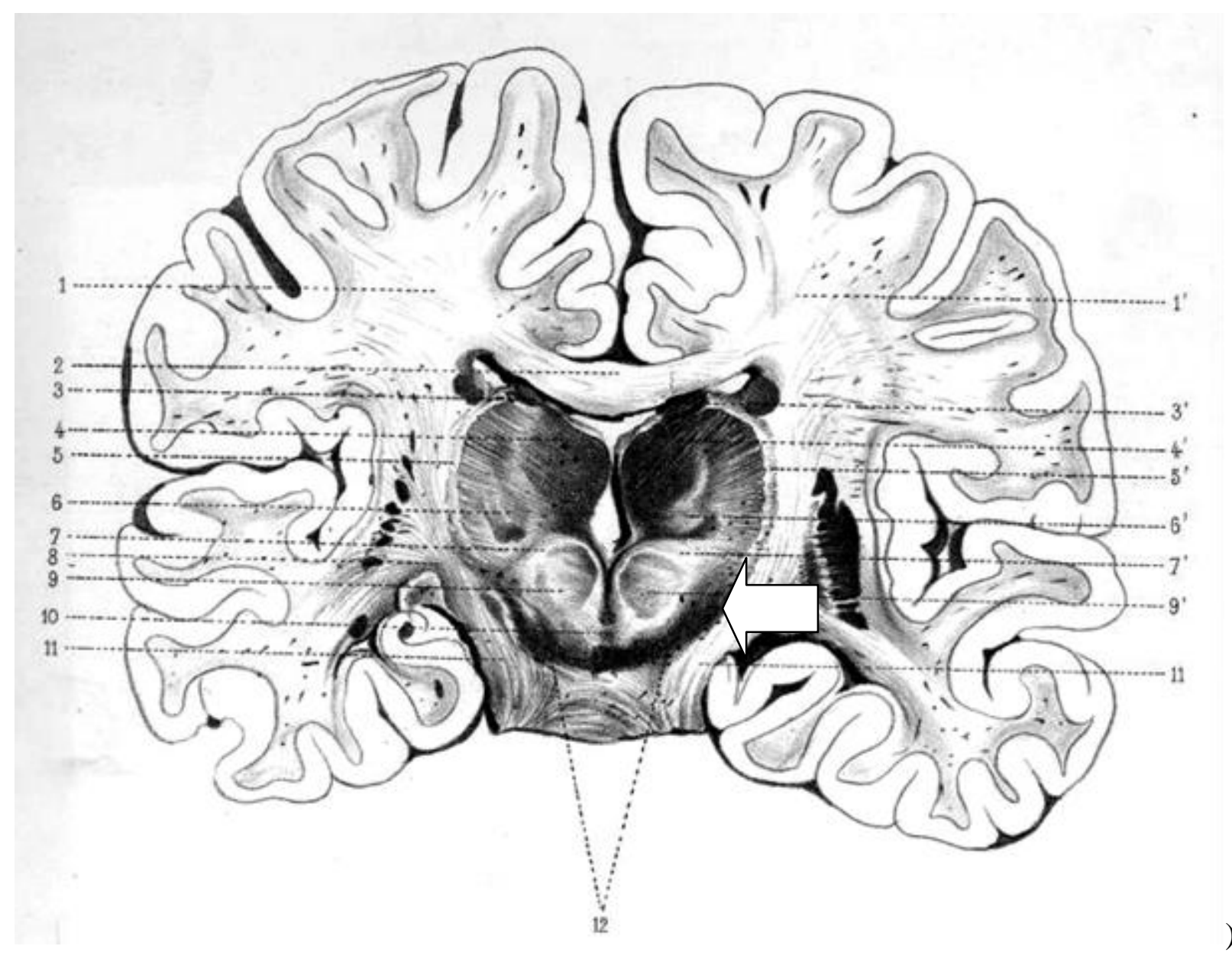

Figure 6. Reproduction of one of the drawings (Plate XXVI) which can be found in Luys' 1865 treatise on the anatomy of human brain, at the level of the subthalamic nucleus (see large arrow). Luys was the first to describe this brain region which he improperly denominated 'accessory band of the superior olives'. This anatomical structure is not clearly labeled on this drawing, but can be recognized as the one prolonging (as the outer and upper part) the 'susbtantia nigra' which is labeled $\mathrm{N}^{\circ} 12$. Reproduction de l'un des dessins (Planche XXVI) qui peut être trouvé dans le traité d'anatomie du cerceau humain de 1865 de Luys, situé au niveau du noyau sous-thalamique (voir la flèche large). Luys fut le premier à décrire cette région du cerveau qu'il appela de façon impropre "bandelette accessoire des olives supérieures ». Cette structure anatomique n'est pas indiquée de façon claire dans la légende de ce dessin, mais elle peut être identifiée comme la région prolongeant en haut et en dehors la « substance noire » («locus niger ») étiquetée $N^{\circ} 12$ (CBIU Santé). 


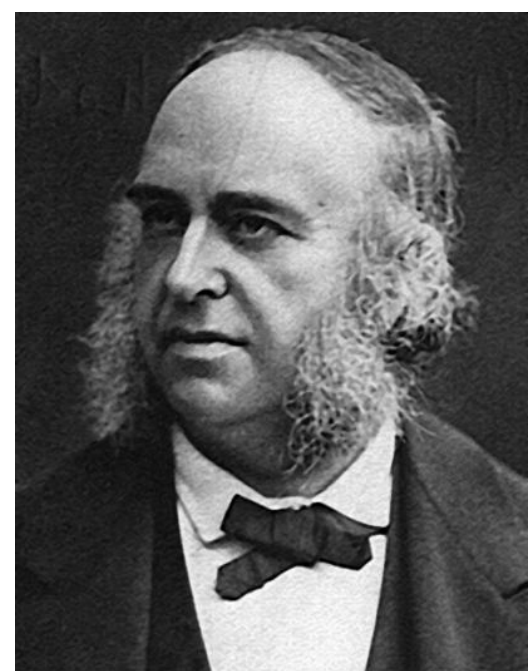

Figure 7. Picture of Broca. Photographie de Broca (Académie Nationale de Médecine).

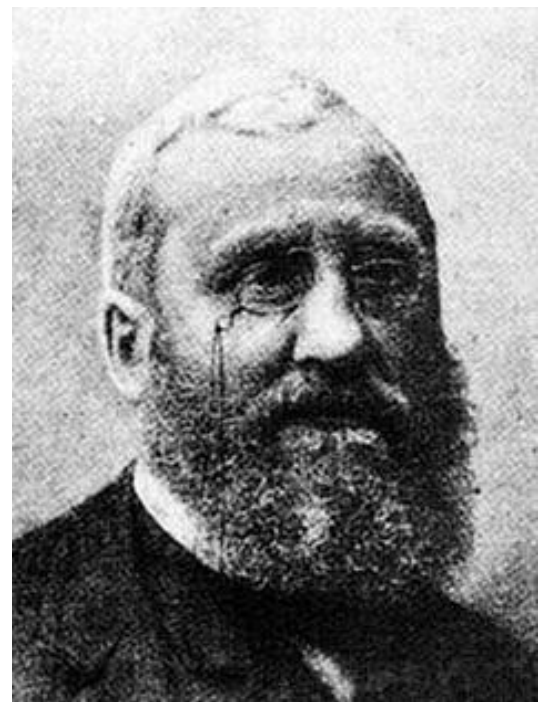

Figure 8. Picture of Ranvier. Portrait de Ranvier (CBIU Santé). 


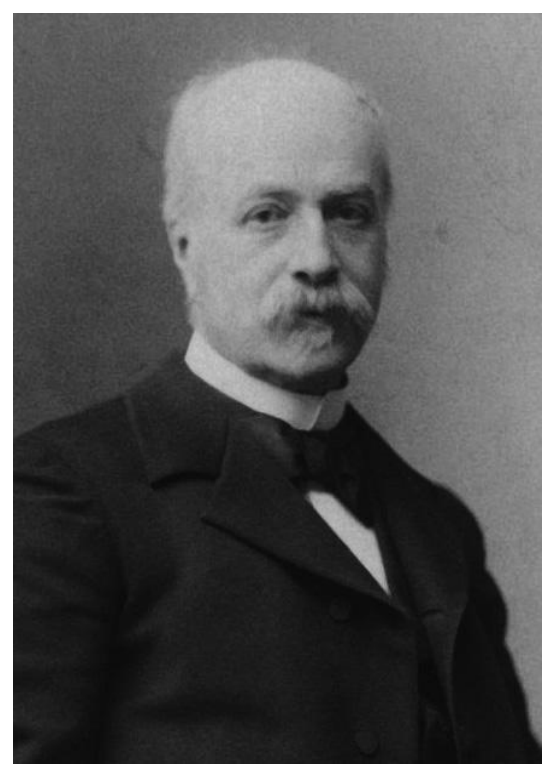

Figure 9. Picture of Cornil. Photographie de Cornil (CBIU Santé).

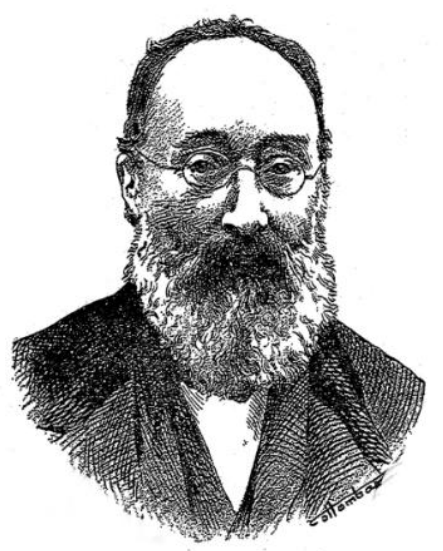

Figure 10. Picture of Gombault. Portrait de Gombault (CBIU Santé).

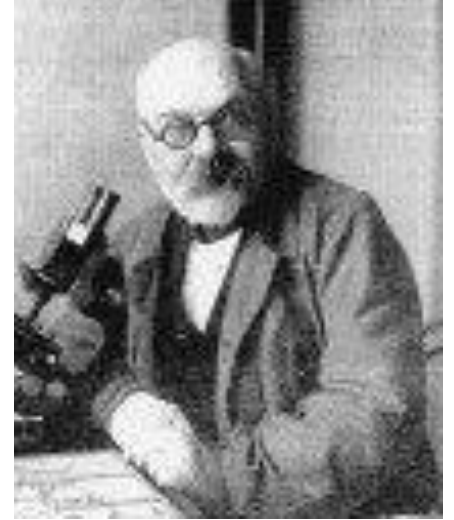

Figure 11. Picture of Nageotte. Photographie de Nageotte. 


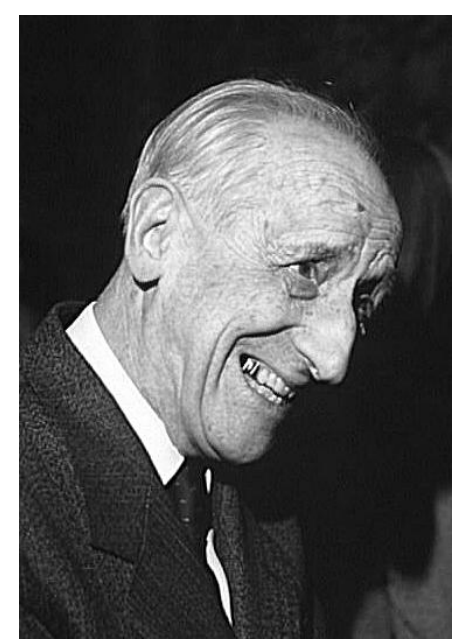

Figure 12. Picture of Couteaux (personal collection). Photographie de Couteaux (collection personnelle de Jacques Poirier).

A

B

C
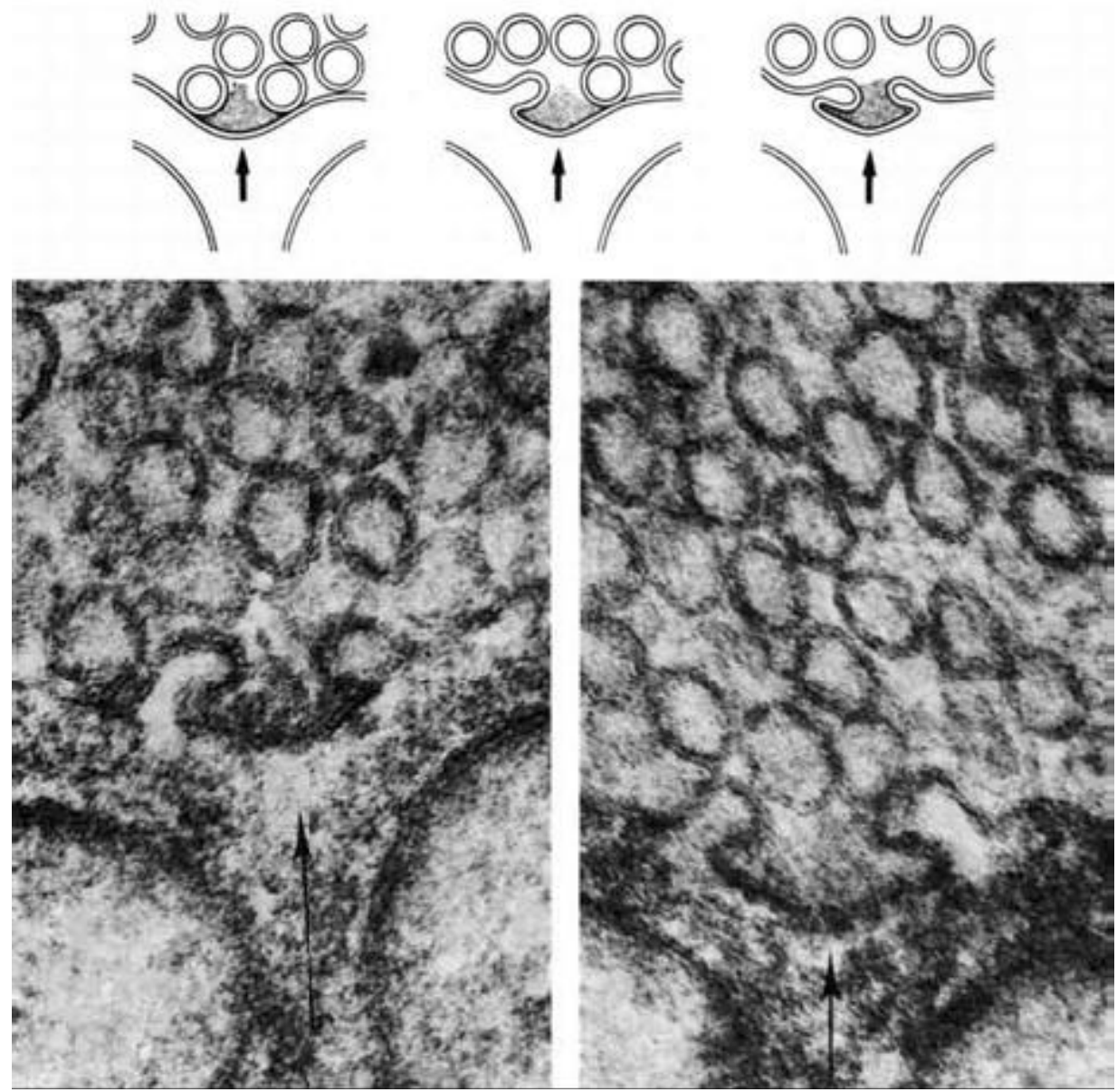

Figure 13. Exocytotic opening of the synaptic vesicles into the synaptic cleft at the level of the active zone (arrow) of the frog neuromuscular junction (magnification, ×205000). Ouverture par exocytose des vésicules synaptiques dans la fente synaptique au niveau de la zone active (flèche) de la junction neuromusculaire de la grenouille (agrandissement X 205000) Reproduced with kind permission of Académie des Sciences. From R. Couteaux and M. Pécot-Dechavassine (1970) Comptes Rendus Hebdomadaires des Séances de l'Académie des Sciences, Série D: Sciences Naturelles, 271, 2346-2349. (Académie des Sciences - Institut de France) 